\title{
Trend Penelitian Penyelesaian Studi di Program Studi Teknologi Pendidikan Universitas Negeri Jakarta
}

\author{
Khaerudin *
}

\section{Info Artikel}

Sejarah Artikel:

Diterima: 15 Juni 2019

Direvisi: 10 Juli 2019

Dipublikasikan: Agustus 2019

e-ISSN: $2620-3081$

p-ISSN: 1411-2744

DOI: https://doi.org/ 10.21009/jtp.v21i2.12978

\begin{abstract}
As an applied scientific discipline Educational Technology (ET) develops by utilizing and supported by other relevant sciences, such as psychology, communication, Information and Communication Technology (ICT), and education. Besides that as a science, Educational Technology is built on a clear foundation of ontological, epistemological, and axiological philosophy. This study aims to find empirical facts about the tendency of ET students to research their final project, viewed from three aspects, namely the paradigm and research methods used, and the ET area as the research domain. The research method used is quantitative descriptive research with a survey approach and is done through document analysis/content (content analysis). The documents analyzed were 577 scientific works, such as theses and dissertations. The results showed that research conducted by ET students of the Jakarta State University over the past 7 years tended to use qualitative research paradigms, research and development methods, and development areas.
\end{abstract}

Keywords: trends, research paradigms, research methods, educational technology areas, applied science

\begin{abstract}
Abstrak: Sebagai disiplin ilmu terapan Teknologi Pendidikan berkembang dengan memanfaatkan dan didukung oleh ilmu-ilmu lain yang relevan, seperti psikologi, komunikasi, teknologi informasi dan komunikasi, dan pendidikan. Di samping itu sebagai sebuah ilmu, Teknologi Pendidikan dibangun di atas landasan filsafat ontologis, epistemologis, dan aksiologis yang jelas. Penelitian ini bertujuan menemukan fakta empiris tentang kecenderungan mahasiswa TP dalam melakukan penelitian sebagai tugas akhir mereka yang dilihat dari tiga aspek, yaitu paradigma dan metode penelitian yang digunakan, serta kawasan TP sebagai domain penelitiannya. Penelitian menggunakan metode deskriptif kuantitatif dengan pendekatan survey dan dilakukan melalui analisis dokumen/isi (content analysis). Dokumen yang dianalisis berupa skripsi, tesis, dan disertasi sebanyak 577 karya ilmiah. Hasil kajian menunjukkan bahwa penelitian yang dilakukan mahasiswa TP UNJ selama 7 tahun terakhir memiliki kecenderungan menggunakan paradigma penelitian kualitatif, metode penelitian dan pengembangan (research and development), dan kawasan pengembangan.
\end{abstract}

Kata kunci: kecenderungan, paradigma penelitian, metode penelitian, kawasan teknologi pendidikan, ilmu terapan

(C) 2019 PPS Universitas Negeri Jakarta

\footnotetext{
* Khaerudin, Fakultas Ilmu Pendidikan, Universitas Negeri Jakarta, Rawamangun Jakarta, 13220 email: khaerudin@unj.ac.id
} 


\section{PENDAHULUAN}

\section{Latar Belakang}

Teknologi Pendidikan (TP) termasuk sebagai sebuah disiplin ilmu terapan (applied science). Artinya ilmu TP berkembang dengan memanfaatkan dan didukung oleh ilmu-ilmu lain yang relevan. Diantara ilmu yang banyak berpengaruh terhadap perkembangan ilmu TP adalah ilmu psikologi, komunikasi, teknologi informasi dan komunikasi, termasuk juga ilmu pendidikan (Miarso, 2004: 111120).

Teknologi Pendidikan memiliki landasan filsafat ontologis, epistemologis dan aksiologis yang jelas (Miarso, 2004: 104-109). Dalam perkembangannya, teknologi pendidikan seharusnya tidak lepas dari ketiga landasan filsafat ilmu tersebut. Sebagai sebuah disiplin ilmu teknologi pendidikan harus dikembangkan berdasarkan apa yang menjadi akar keilmuanya, dan melalui prosedur ilmiah yang sesuai dengan karakteristik ilmu TP, serta hasilnya berkontribusi terhadap pemecahan masalah yang menjadi lingkup dan fokus bidang ilmu TP, yaitu masalah belajar dan pembelajaran.

Mahasiswa program studi TP adalah para akademisi yang memiliki minat dan perhatian terhadap permasalahan-permasalahan yang muncul dalam lingkup bidang TP. Sebagai mahasiswa tentunya mereka memiliki kewajiban untuk menghasilkan karya ilmiah sebagai persyaratan untuk menyelesaikan studinya. Pada sebagian besar mahasiswa untuk memenuhi persyaratan ini mereka melakukan penelitian ilmiah dengan beragam fokus masalah dan beragam pendekatan dan metode penelitian.

Karakteristik dan kecenderungan penelitian yang dilakukan para mahasiswa dalam menyelesaikan studi ini perlu diketahui oleh berbagai pihak khususnya para pengelola program studi dan para dosen TP. Hal ini penting agar proses perkuliahan yang berlangsung di program studi TP memberi bekal pengetahuan (fakta, konsep, prosedur, dan metakognisi) yang memadai kepada para mahasiswa untuk dapat melaksanakan penelitiannya dengan baik.

Berdasarkan pada uraian di atas muncul permasalahan yang harus dicari jawabannya, yaitu (1) Paradigma penelitian apa yang cenderung digunakan oleh para mahasiswa TP dalam melaksanakan penelitiannya? (2) Metode penelitian apa yang cenderung digunakan oleh para mahasiswa TP dalam melaksanakan penelitiannya? dan (3) Kawasan penelitian apa yang cenderung menjadi pilihan para mahasiswa TP dalam melaksanakan penelitiannya?

Penelitian sejenis ini telah dilakukan oleh Khe Foon Hew (National Institute of Education, Singapore) bersama Ugur Kale Nari Kim (Indiana University Bloomington). Penelitiannya bertujuan membantu membuat rasional tentang bidang teknologi pembelajaran dengan menguji dan mengklasifikasi penelitian-penelitian dalam bidang teknologi pembelajaran. Pollard (2004) juga telah melakukan penelitian tentang prioritas penelitian dalam bidang teknologi pendidikan. Hasilnya menyediakan kerangka kerja 8 area prioritas penelitian dan topik penelitian yang spesifik untuk dilakukan dalam teknologi pendidikan. Kedelapan prioritas tersebut adalah belajar, guru, model/strategi pembelajaran, penilaian, isu-isu terkini, sekolah, lingkungan berbasis-web, dan pengaruh eksternal. 


\section{Jenis Penelitian}

Dalam Kamus Oxford (1995) kata Research diartikan sebagai careful study especialy in order to discover new facts or information. Pengertian di atas sejalan dengan pengertian yang dikemukakan oleh Pearson (dalam Whitney, 1960), bahwa penelitian adalah pencarian atas sesuatu secara sistematik dan dilakukan terhadap masalah-masalah yang dapat dipecahkan. Istilah sistematik juga digunakan oleh Kerlinger (1986) yang menyatakan bahwa penelitian adalah suatu penyelidikan yang sistematis, terkendali, empiris, dan kritis mengenai fenomnena-fenomena alam yang dibimbing oleh teori dan hipotesis mengenai hubungan-hubungan yang diduga ada di antara fenomena-fenomena tersebut.

Dengan demikian dapat dinyatakan bahwa penelitian adalah suatu aktivitas mengumpulkan data dan informasi yang dilakukan secara sistematis, terkendali, empiris, kritis, dan juga hati-hati untuk menjawab permasalahan yang ingin dipecahkan.

Secara umum, terdapat dua jenis penelitian, yaitu penelitian ilmiah dan penelitian akademik. Penelitian ilmiah menurut Nazir (1988) adalah penelitian yang (1) berdasarkan pada fakta yang nyata, bukan kira-kira, (2) bebas dari prasangka, berdasarkan pada alasan dan bukti yang lengkap dengan metode pembuktian yang obyektif, (3) menggunakan Analisis, solusi permasalahan dicari dengan analisis yang logis, (4) menggunakan hipotesis, untuk menuntun jalan pikiran peneliti dalam mencapai hasil penelitiannya, (5) menggunakan ukuran yang obyektif, dengan alat ukur yang obyektif pula, (6) menggunakan teknik kuantifikasi, untuk data yang masih memungkinkan dikuantifikasikan. Sedangkan penelitan akademik adalah penelitian yang dilakukan oleh para mahasiswa sebagai persyaratan dalam meyelesaikan studinya. Hal ini sejalan dengan pendapat Kwok yang menyatakan penelitian akademik diperlukan untuk mendapatkan informasi baru atau untuk menghasilkan pengetahuan baru (Karen Kwok. The Chinese University of Hong Kong).

Laporan penelitian mereka biasa disebut dengan skripsi untuk jenjang sarjana (S1), tesis untuk jenjang magister (S2), dan disertasi untuk jenjang doktoral (S3). Penelitian akademik merupakan sarana edukatif dalam mensintesis ilmu yang telah dipelajarinya selama menjadi mahasiswa, sehingga penelitian ini lebih mengutamakan pada validitas internal (prosesnya yang harus betul). Variabel penelitian disesuaikan dengan bidang ilmu masing-masing dan kompleksitas dan kedalaman analisis disesuaikan dengan jenjang pendidikan S1, S2, S3.

\section{Hakikat Teknologi Pendidikan}

Definisi teknologi pendidikan telah mengalami beberapa kali perubahan. Hal ini menunjukkan bahwa teknologi pendidikan sebagai sebuah disiplin ilmu terus berkembang dan dinamis. Perkembangannya dipengaruhi oleh munculnya berbagai permasalahan dalam kegiatan belajar dan pembelajaran pada manusia yang semakin kompleks dan menuntut pemecahan yang efesien dan efektif.

Definisi pertama yang diklaim sebagai cikal bakal lahirnya disiplin ilmu teknologi pendidikan dikenalkan tahun 1963, oleh Departemen of Audiovisual Instruction (DAVI) dari National Education Association (NEA). Pada definisi pertama ini DAVI belum menggunakan istilah teknologi pendidikan, 
tetapi menggunakan istilah audiovisual communications: "Audiovisual communications is that branch of educational theory and practice primarily concerned with the design and use of messages which control the learning process. ... These undertaking include the planning, production, selection, management, and utilization of both components and entire instructional systems" (Januszewski \& Molenda, 2008; 260)

Berkaitan dengan definisi TP, maka pada tahun 1972, DAVI yang merupakan salah satu divisi dari Association for Educational Communications and Technology (AECT) kembali merumuskan definisi teknologi pendidikan yang baru. Pada definisi kedua DAVI sudah menggunakan istilah teknologi pendidikan. Dalam hal ini DAVI mendefinisikan: Educational technology is a field involved in the facilitation of human learning through the systematic identification, development, organization and utilization of a full range of learning resources and through the management of these processes (Januszewski \& Molenda, 2008; 267). Dalam definisi kedua di samping sudah secara eksplisit menggunakan konsep teknologi pendidikan, DAVI juga menegaskan kembali bahwa teknologi pendidikan sebagai sebuah bidang yang terlibat dalam upaya memfasilitasi belajar pada manusia. Upaya fasilitasi yang dilakukan berupa mengidentifikasi, mengembangkan, mengorganisir, dan memanfaatkan secara sistematis semua jenis sumber belajar.

Penegasan untuk fokus pada proses belajar pada manusia, diungkapkan kembali pada definisi ketiga yang dirumuskan oleh AECT pada tahun 1977. Dalam definisi yang ketiga ini dinyatakan bahwa "Educational technology is a complex, integrated process, involving people, procedures, ideas, devices and organization, for analyzing problem and devising, implementing, evaluating and managing solutions to those problems, involves in all aspects of human learning" (Januszewski \& Molenda, 2008; 270). Dalam definisi ketiga ini, teknologi pendidikan mencakup orang, prosedur, ide, alat, dan organisasi untuk menganalisis masalah dan merencanakan, menerapkan, mengevaluasi dan mengelola masalah-masalah pada semua aspek belajar pada manusia. Definisi ini juga sekaligus menunjukkan semakin luasnya bidang garapan dan lingkup aktivitas yang menjadi fokus teknologi pendidikan.

Definisi keempat yang dikeluarkan oleh AECT pada tahun 1994 merupakan definisi teknologi pendidikan yang memiliki pengaruh relatif kuat dalam kajian akademik. Dalam hal ini AECT mendefinisikan "Instructional technology is the theory and practice of design, development, utilization, management, and evaluation of processes and resources for learning" (Januszewski \& Molenda, 2008; 274). Bidang garapan yang mencakup mendesain, mengembangkan, memanfaatkan, mengelola, dan mengevaluasi, lebih dikenal dengan kawasan teknologi pendidikan. Dengan definisi ini AECT ingin menegaskan bahwa kawasan teknologi pendidikan menjadi sangat luas, yaitu mencakup, baik itu teori maupun praktek mendesain, mengembangkan, memanfaatkan, mengelola, dan mengevaluasi proses dan sumber belajar.

Dalam definisi kelima yang dipublikasikan pada tahun 2004 yang juga dikeluarkan oleh AECT, teknologi pendidikan didefinisikan sebagai berikut: "Educational technology is the study and ethical practice of facilitating learning and improving performance by creating, using and managing 
appropriate technological processes and resources" (Januszewski \& Molenda, 2008; 1). Dalam definisi kelima ini terdapat beberapa perbedaan yang signifikan. Pertama, dalam definisi ini tidak lagi menggunakan istilah "teori" tetapi lebih menggunakan konsep "study". Ini menunjukkan bahwa teknologi pendidikan lebih konsern pada kajian-kajian yang bersifat teoritik dan konseptual melalui berbagai penelitian dan praktek. Kedua, memunculkan istilah "ethical practice" yang menegaskan bahwa bidang teknologi pendidikan memperhatikan aspek etis dalam melakukan aktivitas profesinya. Ketiga, dalam definisi ini menyatakan secara eksplisit bahwa bidang TP tidak hanya bagaimana memfasilitasi belajar tetapi juga meningkatkan kinerja, dan keempat, definisi ini mengingatkan bahwa teknologi yang digunakan dalam TP bukanlah selalu teknologi yang canggih tetapi teknologi yang cocok / sesuai (appropriate).

Teknologi Pendidikan dipandang sebagai sebuah ilmu, karena ia memiliki obyek material dan obyek formal yang jelas. Sekalipun obyek materialnya sama dengan disiplin ilmu lain seperti ilmu pendidikan, komunikasi, dan psikologi, yaitu manusia, namun obyek formalnya berbeda yaitu tentang belajar pada manusia (Miarso, 2004: 121).

Di samping itu untuk menegaskan bahwa teknologi pendidikan sebagai sebuah ilmu adalah bahwa teknologi pendidikan memenuhi seluruh cabang filsafat ilmu secara khas yang mencakup ontologi, epistemologi, dan aksiologi. Ontologi dari teknologi pendidikan adalah "Belajar sepanjang hayat, Kesempatan belajar terbatas, Sumber tradisional terbatas, Sumber yang ada dan potential belum didayagunakan, Perlu usaha khusus, Perlu pengelolaan dengan pendekatan baru”.

Epistemologi dalam bidang teknologi pendidikan adalah Isomeristik - penggabungan berbagai disiplin menjadi kebulatan tersendiri; Sistematik - berurutan, terencana dan terarah; Sinergistik berdaya lipat/nilai tambah; Sistemik - menyeluruh/komprehensif; Inovatif - sesuatu yang baru dan belum ada sebelumnya; Integratif - terjalin dalam suatu sistem atau struktur \& tidak terpisahkan.

Sedangkan aksiologi dari teknologi pendidikan adalah Efektivitas dan produktivitas kegiatan; Efisiensi penyelenggaraan; Meluasnya kesempatan pendidikan; Penyesuaian dengan kebutuhan \& kondisi pemelajar; Keserasian dengan perkembangan lingkungan; dan Pendekatan dari bawah (bottomup approach).

Sementara itu yang menjadi kawasan Teknologi Pendidikan mencakup lima kawasan, yaitu kawasan desain, pengembangan, pemanfaatan, pengelolaan, dan penilaian. Bahkan Yusufhadi Miarso menambahkan satu kawasan, yaitu kawasan penelitian. Masing-masing kawasan memiliki lingkup dan fokus yang khas, sebagaimana tergambar dalam gambar berikut: 


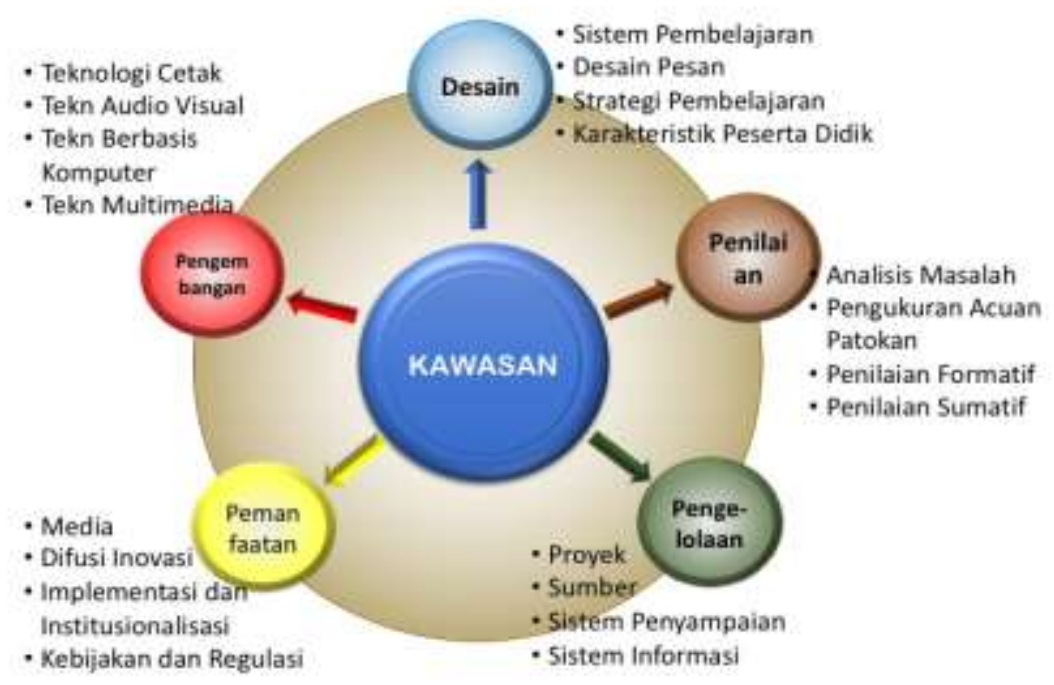

\section{Karakteristik Program Studi Teknologi Pendidikan}

Dalam upaya merespon Perpres No. 8 Tahun 2012 tentang Kerangka Kualifikasi Nasional Indonesia (KKNI), Program Studi Teknologi Pendidikan pada jenjang S1, S2, dan S3, melakukan rekonstruksi kurikulum agar lebih relevan dengan tuntutan Perpres tersebut. Dengan mengacu pada KKNI tersebut maka lulusan S1 Teknologi Pendidikan diharapkan memiliki kompetensi dan kualifikasi setara dengan level 6 dalam KKNI. Demikian juga dengan jenjang S2 dan S3 diharapkan memiliki kualifikasi dan kompetensi yang setara dengan level 8 dan 9 dalam KKNI. Berdasarkan hasil pengembangan kurikulum tersebut, maka saat ini program studi teknologi pendidikan memiliki profil lulusan, capaian pembelajaran yang jelas.

Program studi Teknologi Pendidikan jenjang S1 memiliki profil lulusan yang disebut teknolog pendidikan yang memiiki sifat terbuka, inovatif, serta problem solver dalam merancang proses belajar dan/atau pembelajaran di lintas organisasi, dan jenjang pendidikan.

Dengan merujuk pada definisi terkini yang dirumuskan oleh organisasi profesi tertua dari Teknologi Pendidikan, yaitu Association for Educational Communication and Technology (AECT, 2004) maka kualifikasi yang dimiliki oleh teknolog pendidikan tersebut di atas, yaitu mampu berperan menjadi disainer pembelajaran, pengembang media pembelajaran, dan pengembang teknologi kinerja.

Program studi Teknologi Pendidikan jenjang S2 memiliki target untuk menghasilkan lulusan dengan profil sebagai "Pengembang Sistem Pembelajaran Berbasis Teknologi Terpadu". Sementara program studi teknologi pendidikan pada jenjang S3, memiliki target untuk menghasilkan lulusan dengan profil sebagai "Pengembang Teknologi Pendidikan". 


\section{METODOLOGI PENELITIAN}

Secara umum penelitian ini bertujuan untuk mendapatkan gambaran tentang kecenderungan penelitian bidang TP yang dilakukan oleh para mahasiswa TP dalam memenuhi tugas akhir akademiknya.

Sementara tujuan khususnya adalah untuk mendapatkan gambaran faktual yang komprehensif tentang; 1) Paradigma penelitian yang cenderung dipilih oleh para mahasiswa TP dalam melaksanakan penelitiannya; 2) Jenis metode penelitian yang cenderung digunakan oleh para mahasiswa TP dalam melaksanakan penelitiannya; 3) Kawasan penelitian dalam bidang TP yang cenderung menjadi minat para mahasiswa TP dalam melakukan penelitiannya akademiknya.

Penelitian dilaksanakan di Universitas Negeri Jakarta pada Program Studi Teknologi Pendidikan jenjang S1, S2, dan S3. Metode penelitian yang digunakan adalah penelitian deskriptif kuantitatif dengan pendekatan survey. Van Dalen mengatakan bahwa studi survey merupakan bagian dari studi deskriptif yang salah satunya dapat dilakukan melalui analisis dokumen/isi (content analysis). Bentuk analisis isi dapat dilakukan melalui berbagai kegiatan, salah satu contohnya adalah meneliti dokumen. Dokumen yang dimaksud dalam penelitian ini adalah berupa karya ilmiah: skripsi, tesis, dan disertasi yang ditulis mahasiswa Teknologi Pendidikan Universitas Negeri Jakarta. Secara lebih spesifik, penelitian survey yang digunakan adalah jenis survey longitudinal (Soehartono, 2000:54; Widodo, 2008:43) yaitu suatu survey yang melihat perubahan obyek penelitian dari waktu ke waktu. Pilihan terhadap metode ini didasarkan pada satu pertimbangan bahwa metode ini dinilai paling relevan dengan tujuan penelitian yang ingin dicapai dan permasalahan penelitian yang ingin dipecahkan.

Unit analisis penelitian ini adalah karya ilmiah mahasiswa S1, S2, dan S3 Universitas Negeri Jakarta yang ditulis sebagai persyaratan dalam penyelesaian studinya, yaitu berupa Skripsi, Tesis, dan Disertasi. Karya ilmiah yang menjadi obyek analisis penelitian ini adalah karya ilmiah yang ditulis dan diuji pada 7 tahun terakhir, yaitu dari semester ganjil tahun 2011 sampai dengan semester genap 2017 (Selama 10 semester). Total karya ilmiah yang dianalisis adalah Skripsi (S-1) sebanyak 305 buah, Tesis (S-2) sebanyak 147 buah, dan Disertasi (S-3) sebanyak 125 buah, sehingga secara keseluruhan total karya ilmiah yang berhasil dianalisis sebanyak 577 buah.

Proses pengumpulan data menggunakan instrumen berupa pedoman analisis isi yang berisi aspek-aspek yang berada dalam sebuah karya ilmiah. Aspek-aspek yang dimaksud adalah (1) Paradigma penelitian, (2) Jenis metode penelitian, dan (3) Kawasan penelitian dalam Teknologi Pendidikan. Kajian aspek-aspek tersebut dilihat dari berbagai perspektif, seperti jenjang (S1, S2, dan S3) atau jenis karya ilmiah (Skripsi, Tesis, dan Disertasi) dan tahun penelitian.

Data yang terkumpul dianalisis dengan menggunakan dua pendekatan, yaitu melihat tren secara keseluruhan dengan menggambil rata-rata presentase selama 7 tahun, dan analisis data longitudinal (sering juga disebut "analisis tren"). Analisis ini pada dasarnya melacak bagaimana jawaban untuk pertanyaan spesifik berubah dari waktu ke waktu. Melalui analisis ini diperoleh gambaran tentang trend 
penelitian yang dilakukan mahasiswa Teknologi Pendidikan baik pada jenjang S1, S2, dan S3 dalam rentang 7 tahun ke belakang pada 3 aspek yang diteliti. Di samping itu diketahui apakah terdapat perbedaan trend penelitian yang dilakukan oleh mahasiswa S1, S2, dan S3.

Analisis diawali dengan mengkategorisasi data berdasarkan jenis karya ilmiah (jenjang) dan tahun penyusunan. Kemudian karya ilmiah tersebut diidentifikasi dan ditabulasi berdasarkan aspekaspek obyek penelitian, yang mencakup paradigma dan metode penelitian yang digunakan, dan kawasan dalam Teknologi Pendidikan. Hasil tabulasi disajikan dalam bentuk rata-rata prosentase selama 7 tahun, dan prosentase per aspek dan/atau per tahun, sehingga tampak perubahan pada setiap aspek penelitian yang dilakukan para mahasiswa yang menyelesaikan kuliahnya dari tahun ke tahun. Rata-rata prosentase diperoleh dengan menggunakan rumus berikut:

$$
p=\frac{\text { Jlh per aspek }}{\text { Jlh total }} \times 100
$$

\section{HASIL PENELITIAN DAN PEMBAHASAN}

\section{Deskripsi dan Analisis Data Hasil Penelitian}

Penelitian ini diawali dengan mengidentifikasi sejumlah karya ilmiah yang ditulis dalam rangka penyelesaian studi mahasiswa S-1, S-2, dan S3 Program Studi Teknologi Pendidikan Universitas Negeri Jakarta (TP UNJ), yaitu berupa skripsi, tesis, dan disertasi. Identifikasi karya ilmiah dilakukan dengan mengacu pada sejumlah aspek, yaitu paradigma dan metode penelitian yang mereka gunakan, serta kawasan teknologi pendidikan yang menjadi obyek penelitiannya.

Jumlah karya ilmiah untuk setiap tahun berbeda, sesuai dengan jumlah mahasiswa yang dapat menyelesaikan studinya pada tahun tersebut. Sebaran karya ilmiah tersebut untuk setiap tahun dapat digambarkan dalam tabel berikut:

Tabel 1. Sebaran Karya Ilmiah Mahasiswa Teknologi Pendidikan UNJ 7 Tahun Terakhit

\begin{tabular}{lcccccccc}
\hline \multicolumn{1}{c}{ Karya Ilmiah \& Tahun } & 2011 & 2012 & 2013 & 2014 & 2015 & 2016 & 2017 & Total \\
\hline Skripsi (S-1) & 26 & 65 & 53 & 36 & 34 & 54 & 37 & 305 \\
\hline Tesis (S-2) & 23 & 28 & 31 & 11 & 23 & 15 & 16 & 147 \\
\hline Disertasi (S-3) & 21 & 18 & 11 & 16 & 19 & 32 & 8 & 125 \\
\hline Total & 70 & 111 & 95 & 63 & 76 & 101 & 61 & 577 \\
\hline
\end{tabular}

Sementara itu bila dilihat lebih detail dari aspek-aspek yang menjadi obyek penelitian ini, hasilnya dapat diuraikan sebagai berikut:

\section{Paradigma}

Dilihat secara keseluruhan, penelitian yang dilakukan mahasiswa S-1, S-2, dan S-3 Program Studi Teknologi Pendidikan Universitas Negeri Jakarta cenderung menggunakan paradigma penelitian kualitatif (56\%), diikuti oleh penelitian yang menggunakan paradigma kuantitatif (24\%), dan terakhir penelitian yang menggunakan paradigma mixed methode (20\%): 


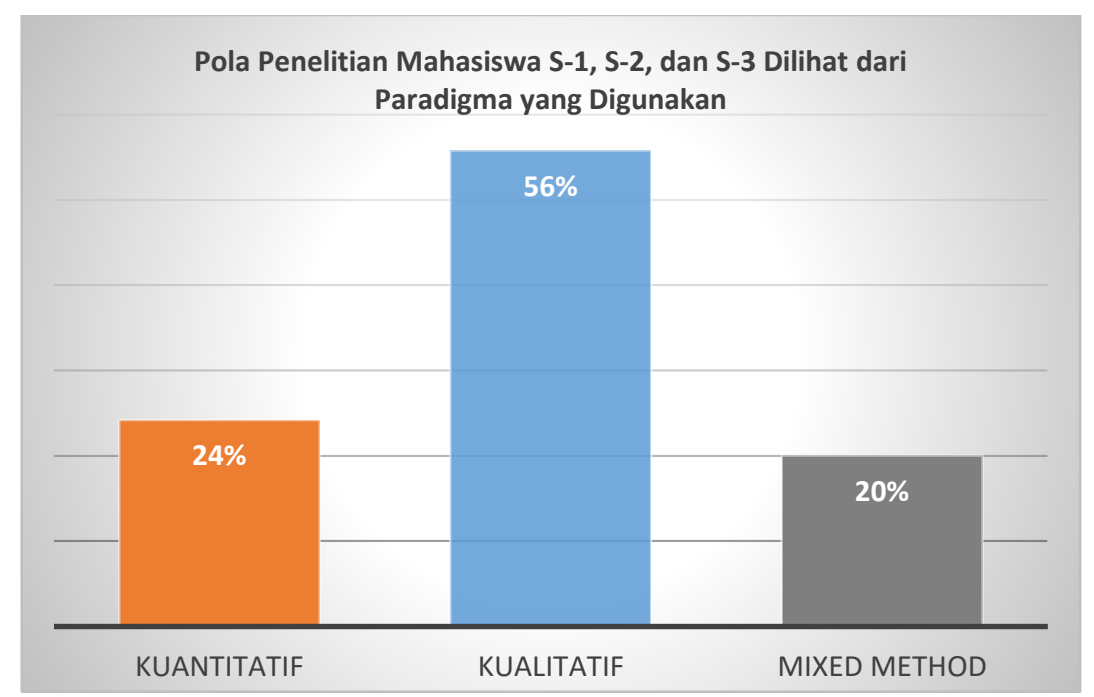

Gambar 1. Sebaran paradigma penelitian mahasiswa S-1, S-2, dan S-3

Dengan demikian, secara keseluruhan dilihat dari aspek paradigma penelitian yang digunakan terdapat kecenderungan penelitian program studi Teknologi Pendidikan secara lebih rinci tergambar dalam tabel berikut:

Tabel 2. Kecenderungan Penelitian Mahasiswa Teknologi Pendidikan UNJ aspek paradigma

\begin{tabular}{|c|c|c|c|c|c|c|c|c|}
\hline & 2011 & 2012 & 2013 & 2014 & 2015 & 2016 & 2017 & Total \\
\hline \multicolumn{9}{|c|}{ Skripsi (S-1) } \\
\hline Kuantitatif & $15 \%$ & $6 \%$ & $6 \%$ & $28 \%$ & $9 \%$ & $13 \%$ & $5 \%$ & $11 \%$ \\
\hline Kualitatif & $85 \%$ & $91 \%$ & $79 \%$ & $67 \%$ & $85 \%$ & $78 \%$ & $76 \%$ & $80 \%$ \\
\hline Mixed Method & $0 \%$ & $3 \%$ & $15 \%$ & $5 \%$ & $6 \%$ & $9 \%$ & $19 \%$ & $9 \%$ \\
\hline Jumlah & $100 \%$ & $100 \%$ & $100 \%$ & $100 \%$ & $100 \%$ & $100 \%$ & $100 \%$ & $100 \%$ \\
\hline \multicolumn{9}{|c|}{ Tesis (S-2) } \\
\hline Kuantitatif & $48 \%$ & $43 \%$ & $61 \%$ & $55 \%$ & $35 \%$ & $47 \%$ & $6 \%$ & $44 \%$ \\
\hline Kualitatif & $13 \%$ & $32 \%$ & $13 \%$ & $45 \%$ & $65 \%$ & $20 \%$ & $50 \%$ & $32 \%$ \\
\hline Mixed Method & $39 \%$ & $25 \%$ & $26 \%$ & $0 \%$ & $0 \%$ & $33 \%$ & $44 \%$ & $24 \%$ \\
\hline Jumlah & $100 \%$ & $100 \%$ & $100 \%$ & $100 \%$ & $100 \%$ & $100 \%$ & $100 \%$ & $100 \%$ \\
\hline \multicolumn{9}{|c|}{ Disertasi (S-3) } \\
\hline Kuantitatif & $48 \%$ & $67 \%$ & $18 \%$ & $50 \%$ & $37 \%$ & $38 \%$ & $38 \%$ & $43 \%$ \\
\hline Kualitatif & $10 \%$ & $17 \%$ & $9 \%$ & $6 \%$ & $16 \%$ & $28 \%$ & $12 \%$ & $16 \%$ \\
\hline Mixed Method & $42 \%$ & $16 \%$ & $73 \%$ & $44 \%$ & $47 \%$ & $34 \%$ & $50 \%$ & $41 \%$ \\
\hline Jumlah & $100 \%$ & $100 \%$ & $100 \%$ & $100 \%$ & $100 \%$ & $100 \%$ & $100 \%$ & $100 \%$ \\
\hline \multicolumn{9}{|c|}{ Total Penelitian (S-1, S-2, dan S-3 TP UNJ) } \\
\hline Kuantitatif & $35 \%$ & $25 \%$ & $25 \%$ & $22 \%$ & $23 \%$ & $25 \%$ & $10 \%$ & $24 \%$ \\
\hline Kualitatif & $38 \%$ & $64 \%$ & $48 \%$ & $63 \%$ & $63 \%$ & $54 \%$ & $60 \%$ & $56 \%$ \\
\hline Mixed Method & $27 \%$ & $11 \%$ & $27 \%$ & $14 \%$ & $15 \%$ & $21 \%$ & $30 \%$ & $20 \%$ \\
\hline Jumlah & $100 \%$ & $100 \%$ & $100 \%$ & $100 \%$ & $100 \%$ & $100 \%$ & $100 \%$ & $100 \%$ \\
\hline
\end{tabular}

Pada jenjang S-1, penelitian yang dilakukan mahasiswa dengan menggunakan metode kualitatif selama 7 tahun terakhir selalu di atas 60\%. Jumlah tertinggi terjadi pada tahun 2012 mencapai 91\%, sedangkan terendah terjadi pada tahun 2014 sebanyak 67\%. Sementara penelitian yang menggunakan mixed method selama 7 tahun terakhir tidak pernah melebihi 20\%. Jumlah tertinggi terjadi pada tahun 2013 dan 2017 yaitu sama sebanyak 19\%, sedangkan terendah terjadi pada tahun 2012 yaitu hanya 3\%. Sedangkan penelitian yang menggunakan metode kuantitatif jumlah tertinggi terjadi pada tahun 2011, 
yaitu mencapai 15\%, sedangkan terendah pada tahun 2017, yaitu 5\%. Dengan demikian bila dilihat dari banyaknya penelitian yang dilakukan per tahun selama 7 tahun terakhir, tidak tampak adanya pola penelitian tertentu. Banyak penelitian dari tahun ke tahun berfluktuasi. Kecenderungan penelitian mahasiswa S-1 TP digtampilkan dalam grafik pada Gambar 2 berikut:

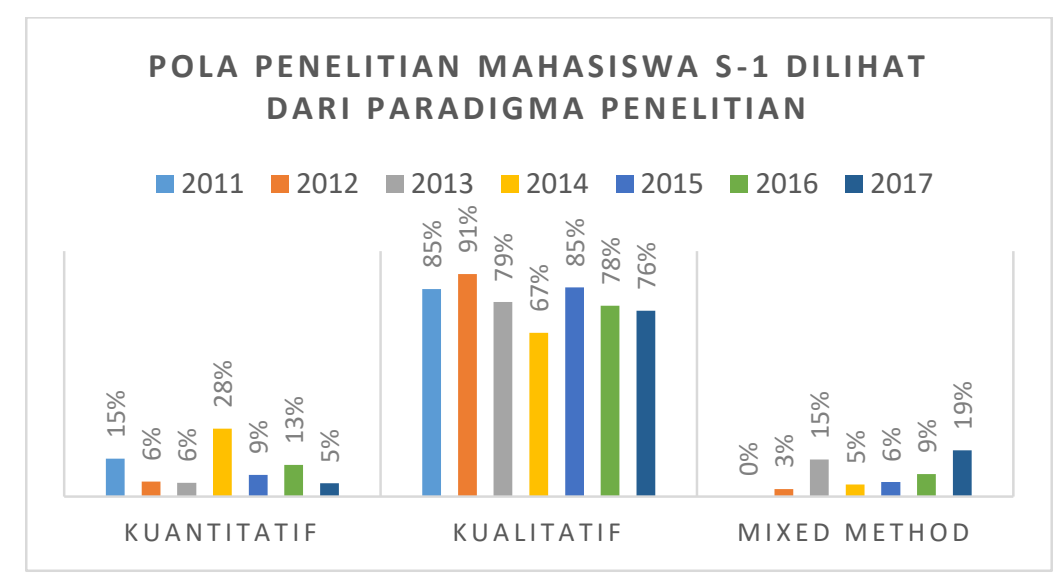

Gambar 2. Pola penelitian mahasiswa S-1 dilihat dari paradigma penelitian

Sementara itu penelitian yang dilakukan mahasiswa S-2, bila dilihat dari paradigma penelitian yang mereka gunakan cenderung menggunakan paradigma kuantitatif, yaitu mencapai rata-rata $44 \%$. Dalam kurun waktu 7 tahun terakhir prosentase mahasiswa yang melakukan penelitian dengan menggunakan paradigma kuantitatif selalu di atas paradigma lainnya, kecuali pada tahun 2015 dan 2017. Prosentase tertinggi terjadi pada tahun 2013 mencapai 61\%, sementara terendah pada tahun 2017 hanya $6 \%$. Sedangkan pada penelitian dengan menggunakan paradigma kualitatif, prosentase tertinggi terjadi pada tahun 2015 mencapai 65\%, dan terendah pada tahun 2011 dan 2013 yang dilakukan oleh 13\% mahasiswa. Namun dilihat dari pola perkembangan dari tahun ke tahun tidak tampak pola yang khas, karena jumlahnya berfluktuasi.

Kondisi di atas menunjukkan bahwa banyaknya penelitian yang dilakukan mahasiswa dari tahun ke tahun tidak membentuk pola tertentu, karena terjadi fluktuasi. Ada kalanya naik di satu tahun, namun pada tahun berikutnya menurun, dan seterusnya.

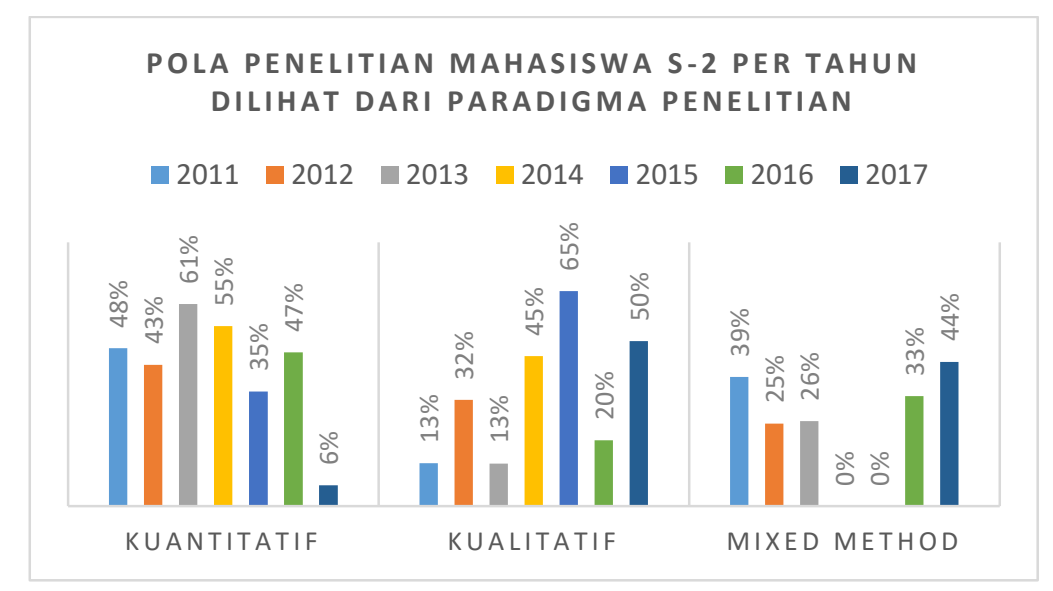

Gambar 3. Pola penelitian mahasiswa S-2 dilihat dari paradigma penelitian 
Demikian juga dengan penelitian yang dilakukan mahasiswa pada jenjang S-3 dalam kurun waktu 7 tahun terakhir, pada penelitian kuantitatif terjadi fluktuatif, dengan prosentase tertinggi terdapat pada tahun 2012 yaitu mencapai 67\%, dan prosentase yang terendah pada tahun 2013 yang mencapai $18 \%$. Sementara pada 3 tahun terakhir kondisinya stabil yaitu sebesar $37 \%$ dan $38 \%$.

Sementara untuk penelitian dengan paradigma mixed methode juga sama, tidak memiliki pola yang khas. Penggunaan paradigma ini tertinggi terjadi pada tahun 2013 yang mencapai 73\%, setelah mengalami lonjakan yang sangat besar dibanding tahun sebelumnya (2012) yang hanya 16\%. Namun pada tahun 2014 kembali turun menjadi hanya 44\%, dan pada akhirnya, pada tahun 2017 kembali naik menjadi 50\%. Demikian juga dengan penelitian yang menggunakan paradigma kualitatif. Secara keseluruhan, selama 7 tahun terakhir tidak pernah mencapai angka 30\%. Tertinggi terjadi pada tahun 2016 yang mencapai $28 \%$, sementara terendah terjadi pada tahun 2014 yang mencapai $6 \%$.

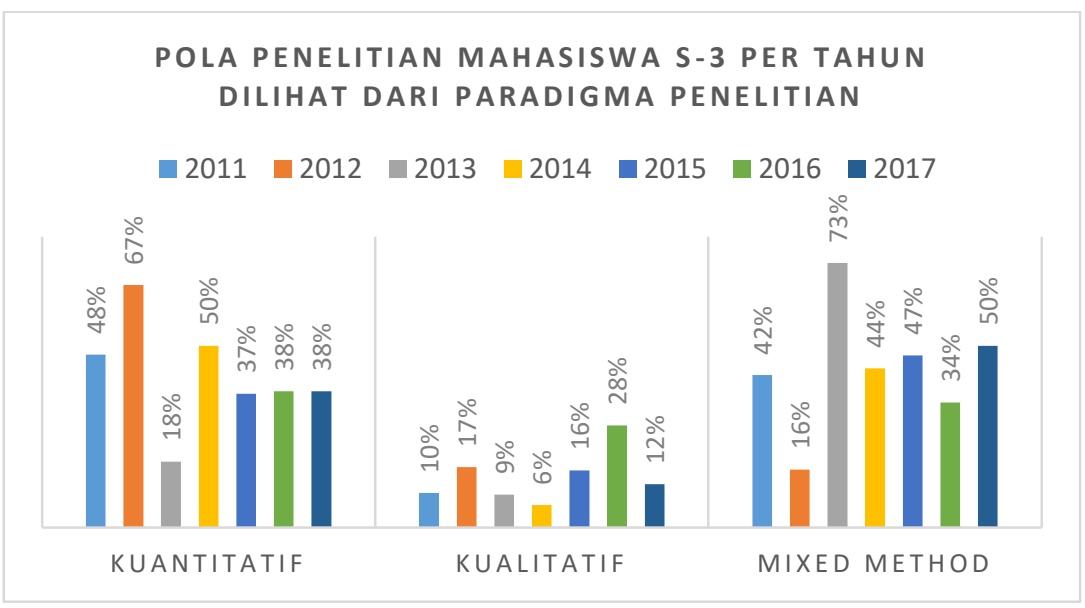

Gambar 4. Pola penelitian mahasiswa S-3 dilihat dari paradigma penelitian

Secara keseluruhan penelitian yang dilakukan mahasiswa S-1, S-2, dan S-3 Program Studi Teknologi Pendidikan Universitas Negeri Jakarta menunjukkan bahwa penelitiannya lebih dominan menggunakan paradigma kualitatif. Sepanjang tahun selama 7 tahun terakhir penelitian yang menggunakan paradigma kualitatif memiliki prosentase tertinggi, yaitu rata-rata 56\%. Prosentase terendah dalam penelitian kualitatif terjadi pada tahun 2011, yaitu hanya $38 \%$, sementara tertinggi terjadi pada tahun 2012 yang mencapai 64\%. Sementara pada tahun berikutnya terjadi fluktuasi, dan diakhiri pada tahun 2017 yang mencapai 60\%.

Sementara itu untuk penelitian yang menggunakan paradigma kuantitatif ada kecenderungan menurun. Pada tahun 2011 menunjukkan sebanyak 35\% penelitian menggunakan paradigma kuantitatif dan merupakan prosentase terbesar, namun sampai pada tahun 2017 hanya tinggal 10\%, yang merupakan prosentase terkecil.

Demikian juga dengan paradigma mixed methode prosentase tertinggi justru pada tahun 2017 yang mencapai $30 \%$. Sementara yang terendah terjadi pada tahun 2012 yang hanya $11 \%$. Pola penelitian 
mahasiswa jenjang S-1, S-2, dan S-3 Teknologi Pendidikan selama 7 tahun terakhir ditampilkan dalam grafik pada Gambar 5 berikut:

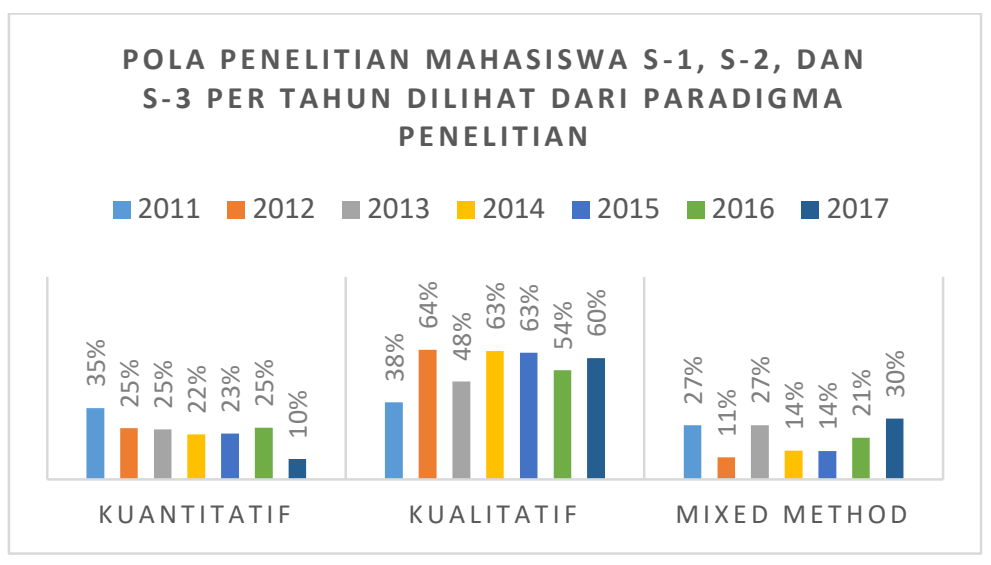

Gambar 5. Pola penelitian mahasiswa dilihat dari paradigma penelitian

\section{Metode}

Dilihat dari aspek metode yang digunakan, penelitian yang dilaksanakan oleh mahasiswa Teknologi Pendidikan sebagian besar menggunakan metode penelitian pengembangan, yaitu digunakan oleh 237 mahasiswa atau 41\%, diikuti oleh metode eksperimen sebanyak 102 orang atau 18\%, survey sebanyak 78 orang atau $14 \%$ dan evaluasi sebanyak 73 orang atau $13 \%$. Khusus penelitian yang menggunakan metode pengembangan, sebagian besar hasil penelitiannya untuk diterapkan dalam lingkup mata kuliah/pelajaran, yaitu sebanyak 107 orang atau 19\%, sedangkan yang produknya untuk digunakan di tingkat kelas/pelatihan dan sekolah/institusi masing-masing 66 dan 64 orang atau $11 \%$.

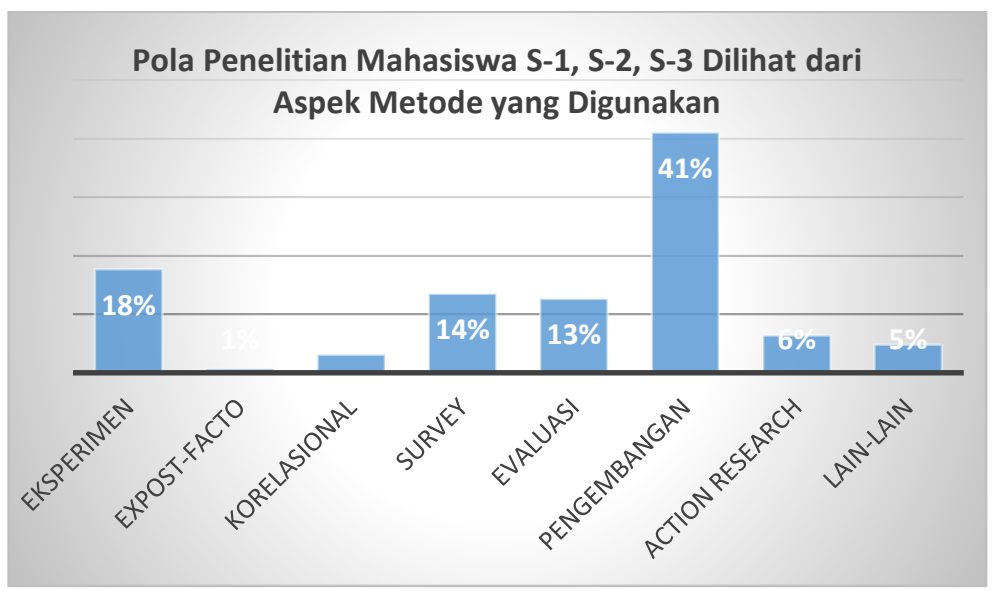

Gambar 6. Pola penelitian mahasiswa dilihat dari aspek metode

Apabila dilikaji lebih detail, dilihat dari tahun ke tahun, terdapat kecenderungan penelitian program studi Teknologi Pendidikan dilihat dari aspek metode penelitian yang digunakan, dapat digambarkan lebih rinci dalam tabel berikut: 
Tabel 3. Penelitian Mahasiswa Teknologi Pendidikan UNJ ditinjau dari aspek metode penelitian

\begin{tabular}{|c|c|c|c|c|c|c|c|c|}
\hline Metode/Tahun & 2011 & 2012 & 2013 & 2014 & 2015 & 2016 & 2017 & Total \\
\hline \multicolumn{9}{|c|}{ Skripsi (S-1) } \\
\hline Eksperimen & $4 \%$ & & $15 \%$ & & & & & $3 \%$ \\
\hline Expost-Facto & & & & & & $2 \%$ & & $0 \%$ \\
\hline Korelasional & & $5 \%$ & & & & $4 \%$ & & $2 \%$ \\
\hline Survey & $23 \%$ & $17 \%$ & $15 \%$ & $28 \%$ & $21 \%$ & $31 \%$ & $19 \%$ & $22 \%$ \\
\hline Evaluasi & $15 \%$ & $9 \%$ & $13 \%$ & $11 \%$ & $21 \%$ & $20 \%$ & $14 \%$ & $14 \%$ \\
\hline Pengembangan & $58 \%$ & $68 \%$ & $55 \%$ & $61 \%$ & $44 \%$ & $35 \%$ & $43 \%$ & $52 \%$ \\
\hline Mata kuliah/ Pelajaran & $35 \%$ & & $19 \%$ & & $6 \%$ & $13 \%$ & & $19 \%$ \\
\hline Kelas/Pelatihan & $19 \%$ & $20 \%$ & $23 \%$ & $14 \%$ & & $13 \%$ & & $18 \%$ \\
\hline Sekolah/Institusi & $4 \%$ & & & & & & & $15 \%$ \\
\hline Action Research & $0 \%$ & $2 \%$ & $2 \%$ & $0 \%$ & $3 \%$ & $7 \%$ & $19 \%$ & $5 \%$ \\
\hline Dan lain-lain & & & & & $6 \%$ & $0 \%$ & $5 \%$ & $1 \%$ \\
\hline Jumlah & $100 \%$ & $100 \%$ & $100 \%$ & $100 \%$ & $100 \%$ & $100 \%$ & $100 \%$ & $100 \%$ \\
\hline \multicolumn{9}{|c|}{ Tesis (S-2) } \\
\hline Eksperimen & $30 \%$ & $32 \%$ & $48 \%$ & $55 \%$ & $35 \%$ & $40 \%$ & $6 \%$ & $35 \%$ \\
\hline Expost-Facto & $4 \%$ & $0 \%$ & $3 \%$ & $0 \%$ & $0 \%$ & $0 \%$ & $0 \%$ & $1 \%$ \\
\hline Korelasional & $0 \%$ & $4 \%$ & $0 \%$ & $0 \%$ & $0 \%$ & $0 \%$ & $0 \%$ & $1 \%$ \\
\hline Survey & $17 \%$ & $11 \%$ & $13 \%$ & $0 \%$ & $0 \%$ & $0 \%$ & $0 \%$ & $8 \%$ \\
\hline Evaluasi & $4 \%$ & $18 \%$ & $0 \%$ & $27 \%$ & $22 \%$ & $13 \%$ & $25 \%$ & $14 \%$ \\
\hline Pengembangan & $4 \%$ & $21 \%$ & $19 \%$ & $9 \%$ & $39 \%$ & $33 \%$ & $50 \%$ & $25 \%$ \\
\hline Mata kuliah/ Pelajaran & $4 \%$ & $18 \%$ & $10 \%$ & $0 \%$ & $0 \%$ & $20 \%$ & $31 \%$ & $12 \%$ \\
\hline Kelas/Pelatihan & $0 \%$ & $4 \%$ & $0 \%$ & $0 \%$ & $0 \%$ & $0 \%$ & $6 \%$ & $1 \%$ \\
\hline Sekolah/Institusi & $0 \%$ & $0 \%$ & $10 \%$ & $9 \%$ & $39 \%$ & $13 \%$ & $13 \%$ & $12 \%$ \\
\hline Action Research & $17 \%$ & $0 \%$ & $3 \%$ & $9 \%$ & $0 \%$ & $7 \%$ & $13 \%$ & $6 \%$ \\
\hline Dan lain-lain & $22 \%$ & $14 \%$ & $13 \%$ & $0 \%$ & $4 \%$ & $7 \%$ & $6 \%$ & $11 \%$ \\
\hline Jumlah & $100 \%$ & $100 \%$ & $100 \%$ & $100 \%$ & $100 \%$ & $100 \%$ & $100 \%$ & $100 \%$ \\
\hline \multicolumn{9}{|c|}{ Disertasi (S-3) } \\
\hline Eksperimen & $24 \%$ & $56 \%$ & $9 \%$ & $38 \%$ & $32 \%$ & $31 \%$ & $25 \%$ & $32 \%$ \\
\hline Expost-Facto & $0 \%$ & $0 \%$ & $9 \%$ & $0 \%$ & $0 \%$ & $0 \%$ & $0 \%$ & $1 \%$ \\
\hline Korelasional & $24 \%$ & $11 \%$ & $9 \%$ & $6 \%$ & $5 \%$ & $0 \%$ & $13 \%$ & $9 \%$ \\
\hline Survey & $0 \%$ & $0 \%$ & $0 \%$ & $0 \%$ & $0 \%$ & $3 \%$ & $0 \%$ & $1 \%$ \\
\hline Evaluasi & $0 \%$ & $0 \%$ & $0 \%$ & $0 \%$ & $11 \%$ & $19 \%$ & $13 \%$ & $7 \%$ \\
\hline Pengembangan & $24 \%$ & $17 \%$ & $27 \%$ & $44 \%$ & $42 \%$ & $34 \%$ & $50 \%$ & $33 \%$ \\
\hline Mata kuliah/ Pelajaran & $19 \%$ & $17 \%$ & $27 \%$ & $25 \%$ & $37 \%$ & $25 \%$ & $38 \%$ & $26 \%$ \\
\hline Kelas/Pelatihan & $5 \%$ & $0 \%$ & $0 \%$ & $19 \%$ & $0 \%$ & $9 \%$ & $13 \%$ & $6 \%$ \\
\hline Sekolah/Institusi & $0 \%$ & $0 \%$ & $0 \%$ & $0 \%$ & $5 \%$ & $0 \%$ & $0 \%$ & $1 \%$ \\
\hline Action Research & $24 \%$ & $11 \%$ & $45 \%$ & $6 \%$ & $5 \%$ & $0 \%$ & $0 \%$ & $11 \%$ \\
\hline Dan lain-lain & $5 \%$ & $6 \%$ & $0 \%$ & $6 \%$ & $5 \%$ & $13 \%$ & $0 \%$ & $6 \%$ \\
\hline Jumlah & $100 \%$ & $100 \%$ & $100 \%$ & $100 \%$ & $100 \%$ & $100 \%$ & $100 \%$ & $100 \%$ \\
\hline \multicolumn{9}{|c|}{ Total (TP UNJ) } \\
\hline Eksperimen & $19 \%$ & $17 \%$ & $25 \%$ & $19 \%$ & $20 \%$ & $16 \%$ & $5 \%$ & $18 \%$ \\
\hline Expost-Facto & $1 \%$ & $0 \%$ & $2 \%$ & $0 \%$ & $0 \%$ & $1 \%$ & $0 \%$ & $1 \%$ \\
\hline Korelasional & $7 \%$ & $5 \%$ & $1 \%$ & $2 \%$ & $3 \%$ & $2 \%$ & $2 \%$ & $3 \%$ \\
\hline Survey & $14 \%$ & $13 \%$ & $13 \%$ & $16 \%$ & $9 \%$ & $18 \%$ & $11 \%$ & $14 \%$ \\
\hline Evaluasi & $7 \%$ & $10 \%$ & $7 \%$ & $11 \%$ & $18 \%$ & $19 \%$ & $16 \%$ & $13 \%$ \\
\hline Pengembangan & $30 \%$ & $48 \%$ & $40 \%$ & $48 \%$ & $42 \%$ & $35 \%$ & $46 \%$ & $41 \%$ \\
\hline Mata kuliah/ Pelajaran & $20 \%$ & $24 \%$ & $17 \%$ & $14 \%$ & $12 \%$ & $18 \%$ & $23 \%$ & $19 \%$ \\
\hline Kelas/Pelatihan & $9 \%$ & $13 \%$ & $13 \%$ & $13 \%$ & $11 \%$ & $10 \%$ & $13 \%$ & $11 \%$ \\
\hline Sekolah/Institusi & $1 \%$ & $11 \%$ & $11 \%$ & $21 \%$ & $20 \%$ & $7 \%$ & $10 \%$ & $11 \%$ \\
\hline Action Research & $13 \%$ & $3 \%$ & $7 \%$ & $3 \%$ & $3 \%$ & $5 \%$ & $15 \%$ & $6 \%$ \\
\hline Dan lain-lain & $9 \%$ & $5 \%$ & $4 \%$ & $2 \%$ & $5 \%$ & $5 \%$ & $5 \%$ & $5 \%$ \\
\hline Jumlah & $100 \%$ & $100 \%$ & $100 \%$ & $100 \%$ & $100 \%$ & $100 \%$ & $100 \%$ & $100 \%$ \\
\hline
\end{tabular}


Bila dilihat lebih detail kecenderungan penelitian yang dilakukan per tahun, baik di S-1, S-2, maupun S-3 tidak ada satu metode penelitian pun yang memiliki pola yang teratur. Pemilihan dan penggunaan metode penelitian oleh para mahasiswa dari tahun ke tahun jumlahnya tidak berpola atau berfluktuasi.

\section{Kawasan Teknologi Pendidikan}

Disiplin ilmu Teknologi Pendidikan memiliki 5 kawasan bidang kajian, yaitu kawasan desain, pengembangan, pemanfaatan, pengelolaan, dan evaluasi. Dilihat dari aspek kawasan kajian ini, teridentifikasi bahwa secara keseluruhan, penelitian yang dilakukan oleh mahasiswa Teknologi Pendidikan Universitas Negeri Jakarta didominasi oleh penelitian dalam kawasan pengembangan, yaitu mencapai 39\% atau 223 karya. Diikuti oleh penelitian dalam kawasan pemanfaatan yang mencapai 32\% atau 187 karya, dan kawasan evaluasi yang mencapai 17\% atau 96 karya. Sementara kawasan pengelolaan dan kawasan desain masing-masing mencapai $8 \%$ atau 44 karya, dan 5\% atau 27 karya. Tampilan data persentase kawasan penelitian mahasiswa Teknologi Pendidikan dapat dilihat pada Gambar 7.

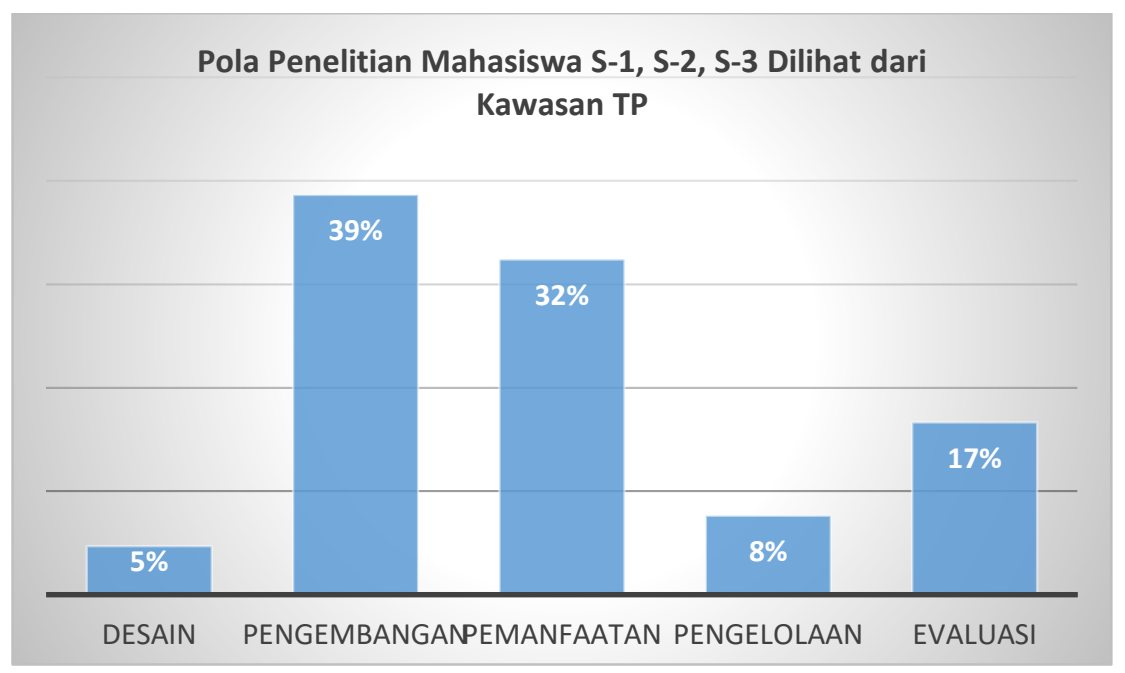

Gambar 7. Pola penelitian mahasiswa dilihat dari aspek kawasan TP

Secara rinci pola penelitian mahasiswa ditinjau dari aspek kawasan yang dipilih ditampilkan pada Tabel 4 berikut:

Tabel 4. Penelitian Mahasiswa Teknologi Pendidikan UNJ ditinjau dari aspek kawasan TP

\begin{tabular}{lcccccccc}
\hline \multicolumn{1}{c}{ Kawasan/Tahun } & 2011 & 2012 & 2013 & 2014 & 2015 & 2016 & 2017 & Total \\
\hline & & $12 \%$ & $11 \%$ & $3 \%$ & $3 \%$ & $15 \%$ & $5 \%$ & $9 \%$ \\
\hline Desain & & $55 \%$ & $45 \%$ & $58 \%$ & $44 \%$ & $33 \%$ & $43 \%$ & $48 \%$ \\
\hline Pengembangan & $58 \%$ & $18 \%$ & $15 \%$ & $19 \%$ & $18 \%$ & $15 \%$ & $19 \%$ & $18 \%$ \\
\hline Pemanfaatan & $27 \%$ & $5 \%$ & $15 \%$ & $8 \%$ & $3 \%$ & $17 \%$ & $3 \%$ & $8 \%$ \\
\hline Pengelolaan & $15 \%$ & $9 \%$ & $13 \%$ & $11 \%$ & $32 \%$ & $20 \%$ & $30 \%$ & $18 \%$ \\
\hline Evaluasi & $100 \%$ & $100 \%$ & $100 \%$ & $100 \%$ & $100 \%$ & $100 \%$ & $100 \%$ & $100 \%$ \\
\hline Jumlah & 0 & $0 \%$ & $0 \%$ & $0 \%$ & $0 \%$ & $0 \%$ & $0 \%$ & $0 \%$ \\
\hline
\end{tabular}




\begin{tabular}{lcccccccc}
\hline \multicolumn{1}{c}{ Kawasan/Tahun } & 2011 & 2012 & 2013 & 2014 & 2015 & 2016 & 2017 & Total \\
\hline Pengembangan & $4 \%$ & $21 \%$ & $19 \%$ & $9 \%$ & $39 \%$ & $33 \%$ & $50 \%$ & $24 \%$ \\
\hline Pemanfaatan & $74 \%$ & $47 \%$ & $65 \%$ & $55 \%$ & $30 \%$ & $46 \%$ & $6 \%$ & $48 \%$ \\
\hline Pengelolaan & $0 \%$ & $7 \%$ & $6 \%$ & $9 \%$ & $9 \%$ & $7 \%$ & $13 \%$ & $7 \%$ \\
\hline Evaluasi & $22 \%$ & $25 \%$ & $10 \%$ & $27 \%$ & $22 \%$ & $13 \%$ & $31 \%$ & $20 \%$ \\
\hline Jumlah & $100 \%$ & $100 \%$ & $100 \%$ & $100 \%$ & $100 \%$ & $100 \%$ & $100 \%$ & $100 \%$ \\
\hline & & & Disertasi (S-3) & & & & \\
\hline Desain & $0 \%$ & $0 \%$ & $0 \%$ & $0 \%$ & $0 \%$ & $3 \%$ & $0 \%$ & $1 \%$ \\
\hline Pengembangan & $24 \%$ & $22 \%$ & $27 \%$ & $44 \%$ & $42 \%$ & $34 \%$ & $50 \%$ & $34 \%$ \\
\hline Pemanfaatan & $76 \%$ & $67 \%$ & $64 \%$ & $44 \%$ & $37 \%$ & $34 \%$ & $13 \%$ & $49 \%$ \\
\hline Pengelolaan & $0 \%$ & $6 \%$ & $0 \%$ & $13 \%$ & $11 \%$ & $6 \%$ & $25 \%$ & $7 \%$ \\
\hline Evaluasi & $0 \%$ & $6 \%$ & $9 \%$ & $0 \%$ & $11 \%$ & $22 \%$ & $13 \%$ & $10 \%$ \\
\hline Jumlah & $100 \%$ & $100 \%$ & $100 \%$ & $100 \%$ & $100 \%$ & $100 \%$ & $100 \%$ & $100 \%$ \\
\hline & & 70 & Total (TP UNJ) & & & $5 \%$ \\
\hline Desain & $0 \%$ & $7 \%$ & $6 \%$ & $2 \%$ & $1 \%$ & $9 \%$ & $3 \%$ & $5 \%$ \\
\hline Pengembangan & $30 \%$ & $41 \%$ & $35 \%$ & $46 \%$ & $42 \%$ & $34 \%$ & $46 \%$ & $39 \%$ \\
\hline Pemanfaatan & $57 \%$ & $33 \%$ & $37 \%$ & $32 \%$ & $26 \%$ & $26 \%$ & $15 \%$ & $32 \%$ \\
\hline Pengelolaan & $0 \%$ & $5 \%$ & $11 \%$ & $10 \%$ & $7 \%$ & $12 \%$ & $8 \%$ & $8 \%$ \\
\hline Evaluasi & $13 \%$ & $13 \%$ & $12 \%$ & $11 \%$ & $24 \%$ & $20 \%$ & $28 \%$ & $17 \%$ \\
\hline Jumlah & $100 \%$ & $100 \%$ & $100 \%$ & $100 \%$ & $100 \%$ & $100 \%$ & $100 \%$ & $100 \%$ \\
\hline
\end{tabular}

Bila ditelusuri dari dimensi waktu (tahun) pelaksanaan penelitian yang dilakukan mahasiswa S1, pola penelitian pada masing-masing kawasan, pada umumnya tidak ada yang berpola khas, sebagian besar berfluktuasi. Kecuali penelitian pada kawasan pengembangan yang terlihat berpola menurun selama 7 tahun terakhir. Penelitian yang dilakukan pada kawasan pengembangan sejak tahun 2011, prosentasenya terus mengalami penurunan, yang semula pada tahun 2011 dilakukan oleh sebanyak 58\% mahasiswa hingga hanya dilakukan oleh $43 \%$ mahasiswa pada tahun 2017. Prosentase terendah terjadi pada tahun 2016 yaitu mencapai $33 \%$.

Sementara penelitian yang dilakukan dalam kawasan pemanfaatan terdapat pola khusus "tiga tahunan”. Artinya setiap 3 tahun terjadi penurunan, namun tahun ke-4 kembali naik. Pada tahun 2011 misalnya prosentase menunjukkan 30\%, pada tahun 2012 turun menjadi 18\%, dan kembali turun pada tahun 2013 menjadi 15\%. Namun pada tahun 2014 sedikit mengalami kenaikan menjadi 19\% dan dua tahun berikutnya menurun lagi, yaitu pada tahun 2015 menjadi 18\% dan pada tahun 2016 menjadi 15\%. Sementara tahun 2017 kembali naik menjadi 19\%. Demikian juga dengan penelitian pada kawasan lain tidak ada yang mencapai 50\%. Paling tinggi ditunjukkan oleh penelitian dalam kawasan evaluasi pada tahun 2017 yang mencapai 30\%, sisanya ada yang hanya mencapai 5\%. Bahkan untuk kawasan desain dan pengelolaan ada yang sampai 0\%, yaitu pada tahun 2011 . 


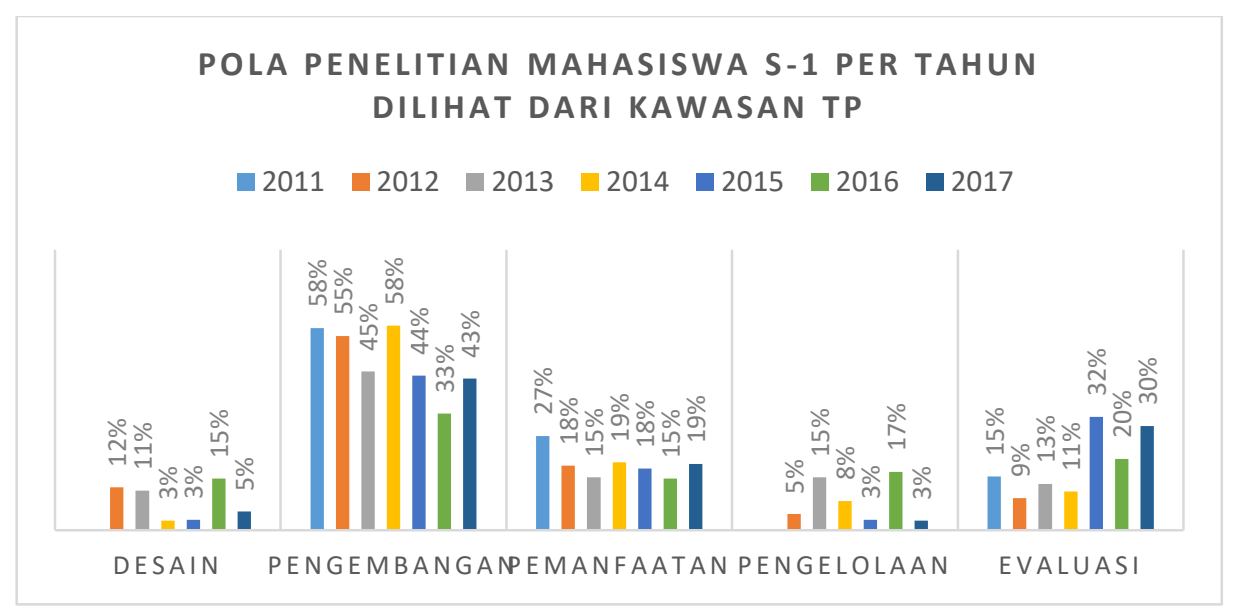

Gambar 8. Grafik penelitian mahasiswa S-1 dilihat dari Kawasan TP

Sedikit berbeda dengan penelitian yang dilakukan mahasiswa S-1, penelitian yang dilakukan mahasiswa S-2, bila dilihat dari dimensi waktu (tahun) pelaksanaan penelitian, pola penelitian pada masing-masing kawasan tidak ada yang berpola khas, semuanya berfluktuasi. Penelitian dalam kawasan pemanfaatan misalnya, pada tahun 2011 mencapai 74\%, namun pada tahun berikutnya mengalami kondisi turun-naik. Pada tahun 2012 turun menjadi 46\%, naik pada tahun 2013 menjadi 65\% dan kembali turun pada tahun 2014 menjadi 55\%. Sementara tahun 2015, 2016, dan 2017 juga sama mengalami kondisi naik-turun. Setelah mengalami penurunan dibanding dengan tahun 2014, pada tahun 2015 mencapai 30\% dan naik menjadi 47\% di tahun 2016, dan turun kembali pada tahun 2017 menjadi hanya $7 \%$. Angka ini merupakan prosentase terendah selama kurun waktu 7 tahun. Hal yang menarik adalah selama 7 tahun terakhir tidak ada satu pun mahasiswa S-2 yang melakukan penelitian pada kawasan desain $(0 \%)$.

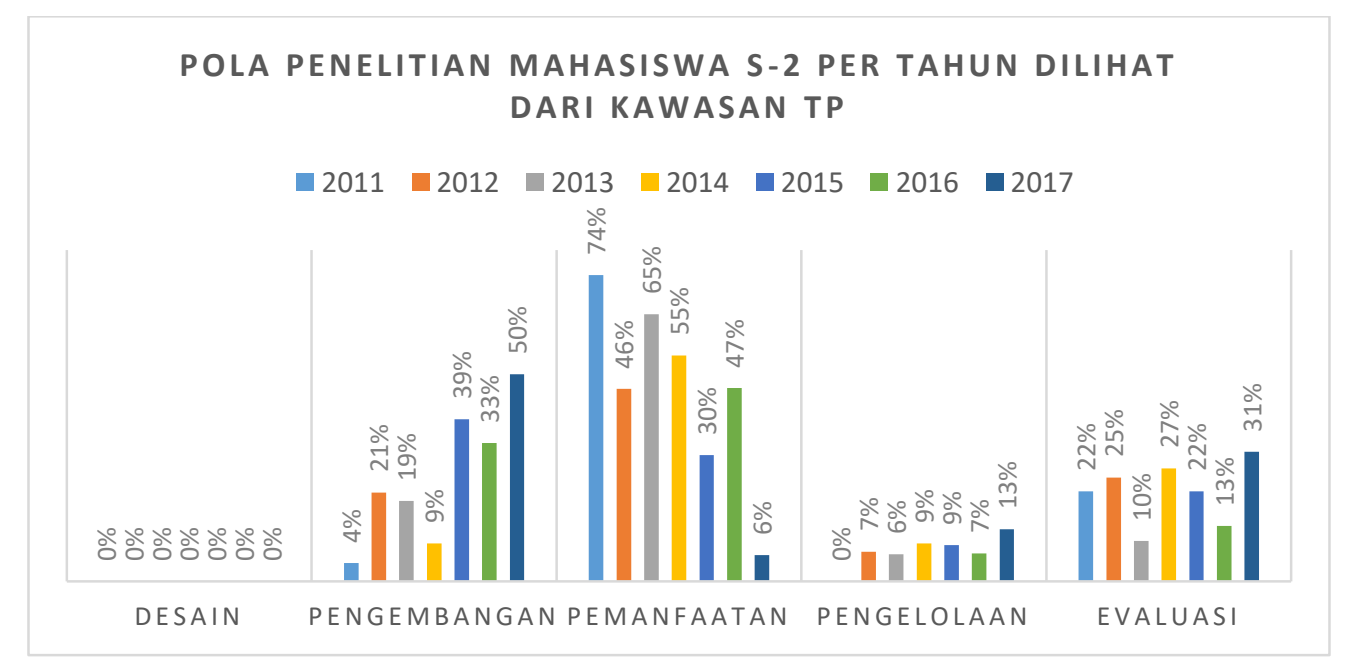

Gambar 9. Grafik penelitian mahasiswa S-2 dilihat dari kawasan TP

Berbeda dengan penelitian yang dilakukan mahasiswa S-2, namun memiliki kemiripan pola dengan penelitian mahasiswa S-1, penelitian yang dilakukan mahasiswa S-3 menunjukkan ada pola yang lebih khas, khususnya untuk penelitian pada kawasan pemanfaatan. Meskipun secara keseluruhan 
penelitian pada kawasan ini merupakan penelitian yang paling dominan, ternyata prosentasenya dari tahun ke tahun mengalami penurunan selama 7 tahun terakhir. Pada tahun 2011, penelitian dalam kawasan ini mencapai 76\%, namun pada tahun-tahun berikutnya terus menurun hingga hanya 13\% pada tahun 2017. Sebaliknya untuk penelitian dalam kawasan pengembangan ada kecenderungan terjadi peningkatan. Kalau pun pada tahun 2012 mengalami penurunan dibanding dengan tahun 2011, namun penurunnya relatif kecil yaitu hanya $2 \%$, sementara pada tahun berikutnya (2013) mengalami kenaikan sampai 5\% dan naik lagi sebesar 17\% pada tahun 2014. Pada dua tahun berikutnya, yaitu tahun 2015 dan 2016 mengalami penurunan sebesar 2\% dan 8\%, namun pada tahun 2017 naik kembali sebesar 17\% sehingga mencapai 50\%. Sementara itu, untuk kawasan lainnya prosentasenya berfluktuasi, dan tidak berpola.

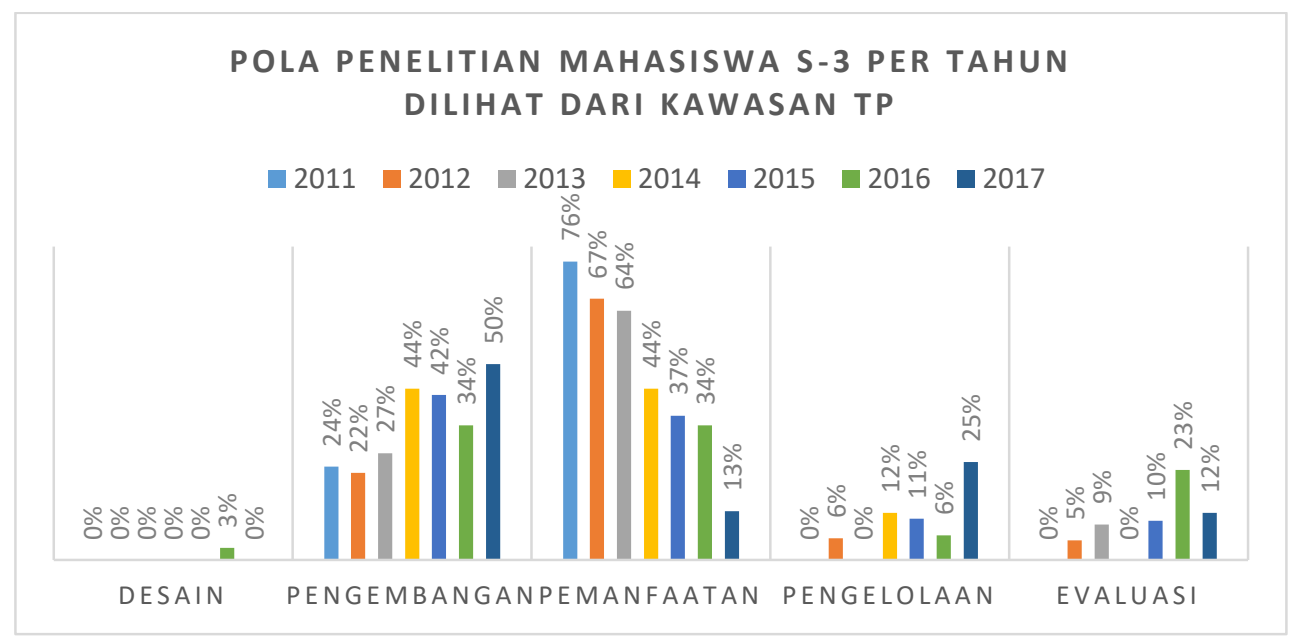

Gambar 10. Grafik penelitian mahasiswa S-3 dilihat dari kawasan TP

Bila dilihat secara keseluruhan, penelitian yang dilakukan mahasiswa Teknologi Pendidikan Universitas Negeri Jakarta selama 7 tahun terakhir, pada kawasan pemanfaatan menunjukkan adanya pola yang menurun dan sebaliknya pada kawasan pengembangan menunjukkan adanya kecenderungan meningkat. Penelitian yang dilakukan pada kawasan pemanfaatan, pada tahun 2011 menunjukkan prosentase sebesar 57\% dan pada tahun berikutnya menurun hingga 33\% dan pada akhirnya pada tahun 2017 hanya mencapai 15\%. Sementara untuk penelitian pada kawasan pengembangan menunjukkan adanya peningkatan, yaitu yang semula, pada tahun 2011 hanya 30\% meningkat menjadi 46\% pada tahun 2017, sekalipun sempat terjadi penurunan pada tahun 2016 yang mencapai 34\% namun tetap lebih besar dari kondisi tahun 2011. Grafik pola penelitian mahasiswa ditinjau dari aspek kawasan TP yang dipilih ditampilkan pada gambar 10 berikut: 


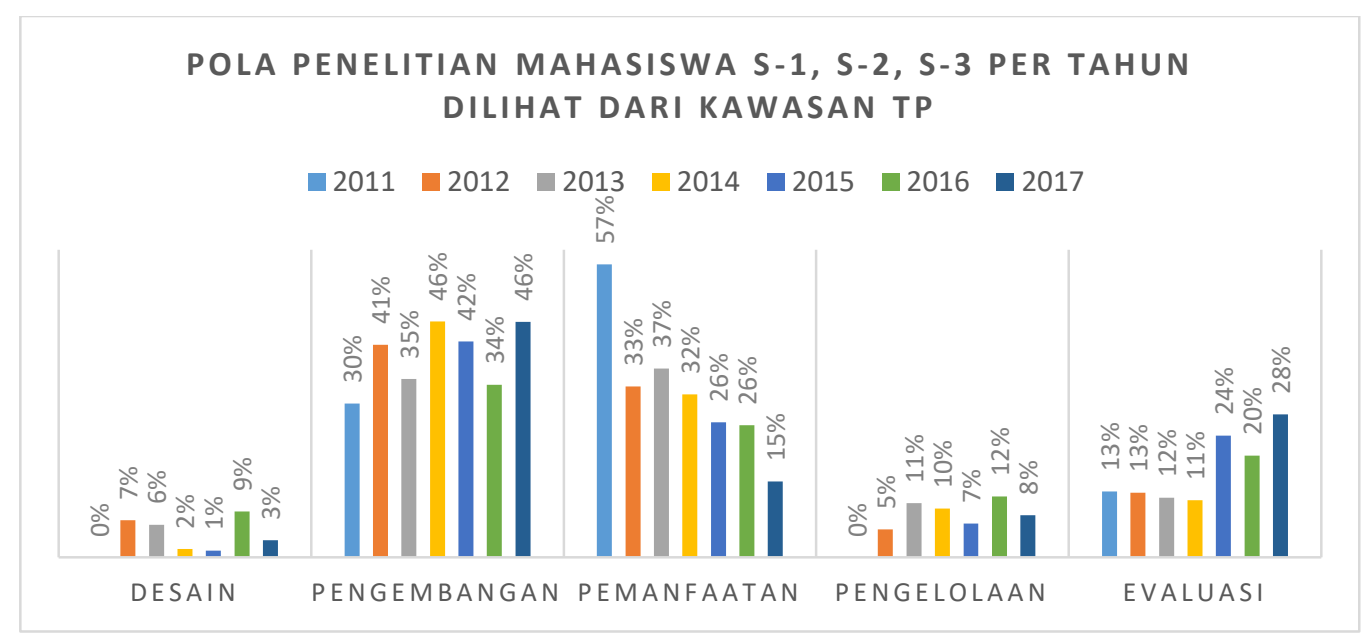

Gambar 10. Grafik penelitian mahasiswa S-1, S-2, dan S-3 dilihat dari kawasan TP

\section{Pembahasan Hasil Penelitian}

Mencermati data karya ilmiah yang dihasilkan mahasiswa S-1 (Skripsi), S-2 (Tesis), dan S-3 (Disertasi) Program Studi Teknologi Pendidikan UNJ selama kurun waktu 7 tahun terakhir apabila dilihat dari aspek paradigma penelitian yang mereka gunakan terdapat perbedaan antara penelitian yang dilakukan mahasiswa S-1 dengan penelitian mahasiswa S-2 dan S-3. Penelitian yang dilakukan mahasiswa S-1 pada umumnya menggunakan paradigma penelitian kualitatif, yaitu mencapai 83,4\%, sementara pada mahasiswa S-2 menggunakan paradigma kuantitatif, yaitu 44\%. Sedangkan penelitian mahasiswa S-3 relatif seimbang antara paradigma kuantitatif dan mixed methode yaitu 43\% menggunakan paradigma kuantitatif dan $41 \%$ menggunakan paradigma mixed methode.

Pada penelitian mahasiswa S-1 data tersebut sejalan dengan mayoritas metode yang digunakan yaitu metode penelitian dan pengembangan ( $R$ and $D)$. Demikian juga dengan data penelitian mahasiswa S-2 yang didominasi oleh paradigma kuantitatif, sejalan dengan metode penelitian yang mereka gunakan yaitu berupa metode eksperimen. Konsistensi juga terjadi pada penelitian mahasiswa S-3, dimana penggunaan metode penelitian eksperimen dan pengembangan juga seimbang. Kondisi ini menunjukkan bahwa masing-masing level memiliki konsern dan kecenderungan yang berbeda dalam hal paradigma dan metode yang mereka gunakan. Hal yang menarik adalah metode yang menjadi kecenderungan digunakan oleh mahasiswa S-3 yaitu adanya keseimbangan antara metode eksperimen (32\%) dan pengembangan (33\%), dimana kedua metode tersebut menjadi dominan di S-1 dan S-2. Metode penelitian yang digunakan mahasiswa S-1 didominasi oleh metode pengembangan, yang mencapai 52\%, sedangkan pada mahasiswa S-2 didominasi oleh metode eksperimen, yang mencapai 35\%. Namun demikian bila dilihat secara keseluruhan, untuk mahasiswa S-1, S-2, dan S-3 TP UNJ, prosentase yang terbesar dalam penggunaan metode penelitian ada pada metode pengembangan, yaitu mencapai $41 \%$. Hal ini bisa terjadi karena penelitian yang yang dilakukan mahasiswa S-1 dan sebagian S-3 cenderung menggunakan metode pengebangan. 
Bila dicermati pada aspek kawasan teknologi pendidikan, penelitian yang dilakukan mahasiswa TP S-1, S-2, dan S-3 selama 7 tahun terakhir berada pada kawasan pengembangan (39\%) dan pemanfaatan (32\%). Namun bila dilihat per strata memiliki sedikit perbedaan. Pada mahasiswa S-1 cenderung melakukan penelitian pada kawasan pengembangan yang diikuti oleh kawasan pemanfaatan dan evaluasi, sementara penelitian yang dilakukan mahasiswa S-2 dan S-3, sama-sama cenderung di kawasan pemanfaatan dan diikuti oleh kawasan pengembangan.

Perkembangannya per tahun menunjukkan bahwa penelitian pada kawasan pengembangan cenderung mengalami perkembangan, sekalipun pada tahun 2013 dan 2016 mengalami penurunan dibanding dengan tahun sebelumnya, namun tetap di atas prosentase pada tahun 2011 yaitu sebesar (30\%). Sementara penelitian pada kawasan pemanfaatan ada kecenderungan menurun yang cukup tajam. Jumlah penelitian pada kawasan pemanfaatan pada tahun 2011 sebanyak 57\% menjadi hanya 15\% pada tahun 2017.

Mencermati deskripsi dan analisis data di atas tampak bahwa kesimpulan pada setiap aspek saling berhubungan satu sama lain. Kesimpulan penelitian pada aspek kawasan yang diteliti yang didominasi oleh kawasan pengembangan sangat terkait erat dengan metode penelitian yang digunakan dalam penelitian, yang didominasi oleh metode penelitian dan pengembangan ( $R$ and $D)$. Dengan demikian secara umum penelitian yang dilakukan mahasiswa Teknologi Pendidikan Universitas Negeri Jakarta dapat disimpulkan konsisten antara kawasan, paradgima, dan metode penelitian yang mereka gunakan.

\section{KESIMPULAN DAN IMPLIKASI}

\section{Kesimpulan}

Berdasarkan deskripsi dan analisis data di atas dapat disimpulkan bahwa:

Pertama; Paradigma penelitian yang paling dominan digunakan mahasiswa TP UNJ dalam rentang waktu 7 tahun terakhir adalah paradigma kualitatif yaitu sebesar 54\%. Namun demikian bila dilihat per strata terdapat perbedaan yang cukup mencolok, dimana penelitian yang dilakukan mahasiswa S-1 cenderung menggunakan paradigma kualitatif, sementara mahasiswa S-2 cenderung menggunakan paradigma kuantitatif, sedangkan mahasiswa S-3 cenderung menggunakan paradigma kuantitatif dan mixed methode. Bila dilihat perkembangannya per tahun, penelitian dengan paradigma kuantitatif cenderung menurun, yaitu dari sebesar 36\% pada tahun 2011 menjadi hanya 10\% pada tahun 2017. Sebaliknya untuk penelitian dengan paradigma kualitatif ada kecenderungan meningkat, yaitu dari 39\% pada tahun 2011 menjadi 61\% pada tahun 2017. Sekalipun keduanya mengalami fluktuasi yang cukup tajam selama rentang waktu 7 tahun tersebut.

Kedua; Metode yang paling dominan digunakan oleh mahasiswa TP UNJ (secara keseluruhan) adalah metode penelitian dan pengembangan (Research and Developent). Namun demikian bila dilihat lebih detail per strata, penelitian yang dilakukan mahasiswa S-2 berbeda dengan yang dilakukan mahasiswa S-1 dan S-3, yaitu cenderung menggunakan metode penelitian eksperimen. Sedangkan penelitian yang dilakukan mahasiswa S-3 cenderung terdapat keseimbangan antara yang menggunakan 
metode eksperimen dan yang menggunakan metode penelitian dan pengembangan. Bila dilihat perkembangan per tahun, metode penelitian yang digunakan mahasiswa TP UNJ tidak berpola, karena antara satu tahun ke tahun berikutnya berfluktuasi. Namun bila dilihat dari perbedaan prosentase antara tahun 2011 dengan 2017 pada penelitian pengembangan terdapat kecenderungan meningkat, yaitu dari $30 \%$ pada tahun 2011 menjadi 46\% pada tahun 2017. Sebaliknya untuk penelitian dengan menggunakan metode eksperimen ada kecenderungan menurun, yaitu dari 19\% pada tahun 2011 menjadi hanya 5\% pada tahun 2017.

Ketiga: dari 5 kawasan Teknologi Pendidikan, kawasan yang paling dominan diteliti oleh mahasiswa TP UNJ adalah kawasan pengembangan (39\%) dan pemanfaatan (32\%). Namun apabila dilihat per strata, pada mahasiswa S-1 cenderung melakukan penelitian pada kawasan pengembangan yang diikuti oleh kawasan pemanfaatan dan evaluasi, sementara penelitian yang dilakukan mahasiswa S-2 dan S-3, sama-sama cenderung di kawasan pemanfaatan dan diikuti oleh kawasan pengembangan. Demikian juga apabila dilihat dari perkembangannya per tahun, pada kawasan pengembangan tidak ada pola yang khas karena berfluktuatif. Namun apabila dilihat dari selisih antara prosentase tahun 2011 dan 2017 terdapat kecenderungan terjadi peningkatan, yaitu dari 30\% pada tahun 2011 menjadi 46\% pada tahun 2017 atau terjadi peningkatan sebesar 16\%. Sementara pada kawasan pemanfaatan terdapat kecenderungan menurun, dari tahun ke tahun terus mengalami penurunan, sehingga apabila dilihat dari selisih prosentase tahun 2011 (57\%) dengan 2017 (15\%) terdapat selisih yang cukup besar yaitu mencapai $42 \%$.

\section{DAFTAR RUJUKAN}

Anglin, Gary J. (Editor). 2011. Instructional Technology: Past, Present, and Future. Santa Barbara: ABC-CLIO, LLC

Januszewski, Alan, Michael Molenda. 2008. Educational Technology: A definition with Commentary. New York: Lawrence Erlbaum Associates.

Kerlinger, Fred N. 2004. Asas-asas Penelitian Behavioral. Yogyakarta: UGM Press.

Khe Foon Hew, Ugur Kale Nari Kim. Past Research In Instructional Technology: Results Of A Content Analysis Of Empirical Studies Published In Three Prominent Instructional Technology Journals From The Year 2000 Through 2004. J. Educational Computing Research, Vol. 36(3) 269-300, 2007

Miarso, Yusufhadi. 2004. Menyemai Benih Teknologi Pendidikan. Jakarta: Prenada Media.

Irawan Soehartono. 2000. Metode Penelitian Sosial: Suatu Teknik Penelitian Bidang Kesejahteraan Sosial dan Ilmu Sosial lain. Bandung: PT Remaja Rosdakarya.

Pollard, Constance \& Richard Pollard (2004) Research Priorities in Educational Technology, Journal of Research on Technology in Education, 37:2, 145-160, DOI: 10.1080/15391523.2004. 10782430

Seels, Barbara B., Rita C. Richey. 1994. Instructional Technology: Definition and Domain of The Field. Terjemahan: Dewi Salma, dkk.

Singarimbun, Masri dan Effendi, Sofian. 1995. Metode Penelitian Survey. Jakarta: PT Pustaka LP3ES 
Reiser, Robert A., John V. Dempsey. 2007. Trends and Issues in Instructional Design and Technology. New Jersey: Pearson Education, Inc.

Widodo, T. 2008. Metode Penelitian Kuantitatif. Solo: UNS Press 